\title{
EMERY BIOMASS GASIFICATION POWER SYSTEM
}

\author{
FINAL REPORT \\ No. 41351R01
}

Project Period: Start 10/01/01 End 05/31/02

Principal Authors:

Benjamin Phillips, Scott Hassett, Harry Gatley

Issue date: November $27^{\text {th }}, 2002$

DOE Award \# DE-FC26-01NT41351

\author{
Project Participants \\ EMERY RECYCLING CORPORATION \\ (now Emery Energy Company, LLC) \\ 444 East 200 South \\ Salt Lake City, UT 84111
}

Idaho National Engineering and Environmental Laboratory

P.O. Box 1625

Idaho Falls, ID 83415-5937

Combustion Resources, LLC

1711 N. 1350 W.

Provo, UT 84604

Biomass Energy Foundation (Dr. Tom Reed)

1810 Smith Rd. - Box 1392

Golden, CO 80401

Southeastern Public Service Authority

4 Victory Blvd.

Portsmouth, VA 23702

\section{DISCLAIMER}

"This report was prepared as an account of work sponsored by an agency of the United States Government. Neither the United States Government nor any agency thereof, nor any of their employees, makes any warranty, express or implied, or assumes any legal liability or responsibility for the accuracy, completeness, or usefulness of any information, apparatus, product, or process disclosed, or represents that its use would not infringe privately owned rights. Reference herein to any specific commercial product, process, or service by trade name, trademark, manufacturer, or otherwise does not necessarily constitute or imply its endorsement, recommendation, or favoring by the Unites states Government or any agency thereof. The views and opinions of authors expressed herein do not necessarily state or reflect those f the United States Government or any agency thereof." 


\section{Table of Contents}

ABSTRACT 4

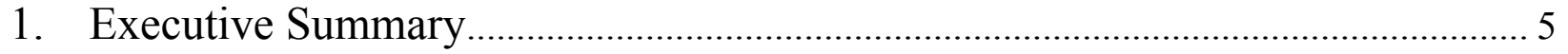

1.1. Gasifier Modeling ................................................................................................ 5

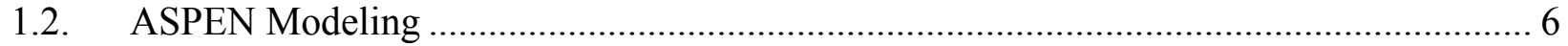

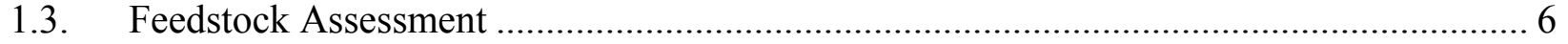

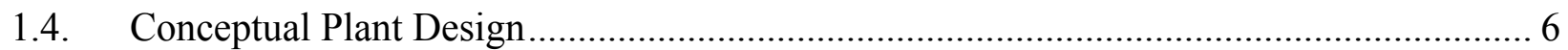

1.5. Economic and Financial Analysis....................................................................... 7

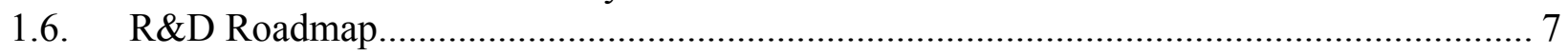

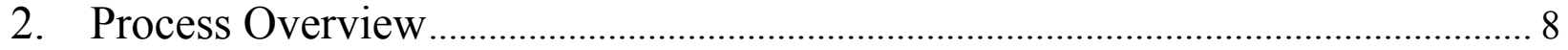

2.1. Technology Background .................................................................................... 8

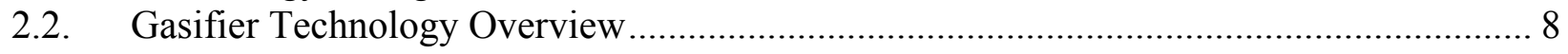

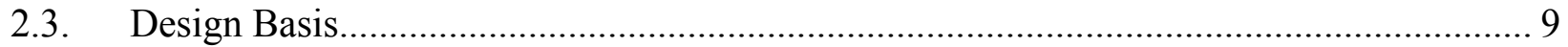

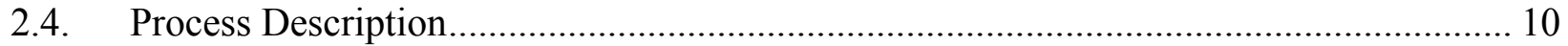

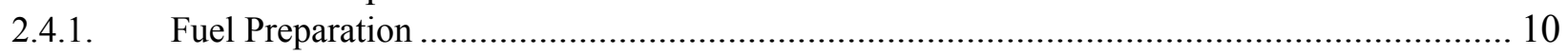

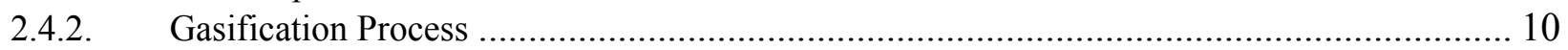

2.4.3. Heat Recovery / Steam Generation from Syngas ....................................................... 11

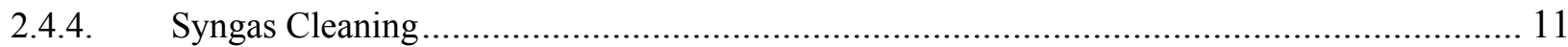

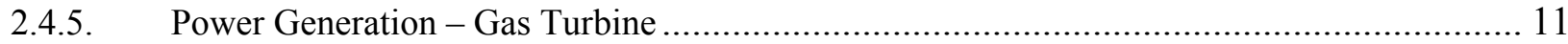

2.4.6. Power Generation - Steam Turbine..................................................................... 12

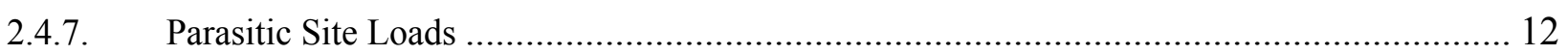

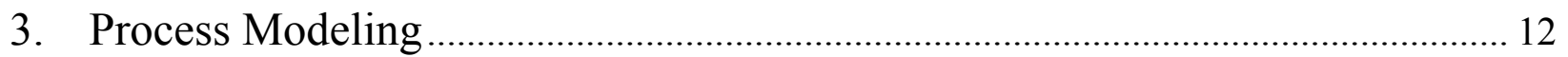

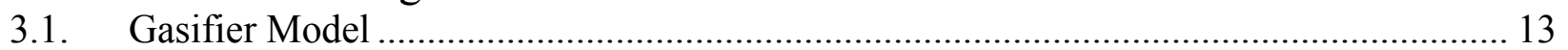

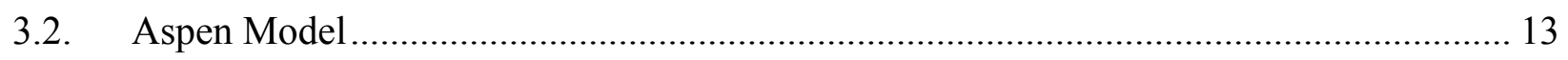

4. Technical, Environmental and Economic Performance ...................................... 14

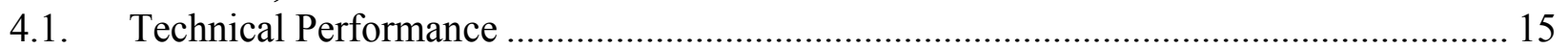

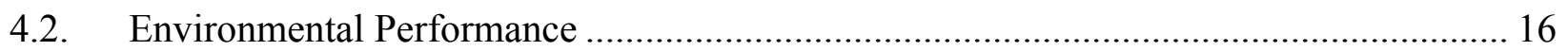

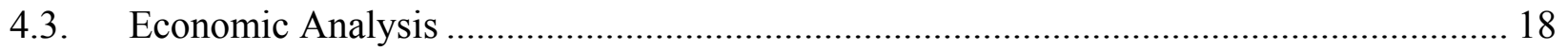

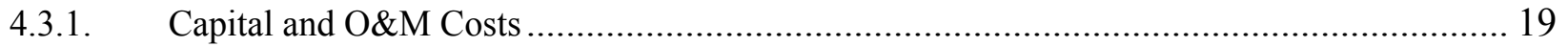

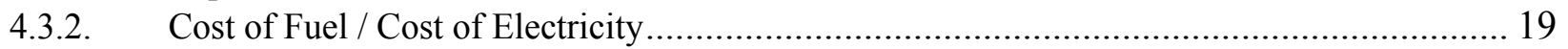

5. Technology Development Roadmap .................................................................... 21

5.1. Technology Development Phases ....................................Error! Bookmark not defined.

6. Market Analysis....................................................................................................... 23

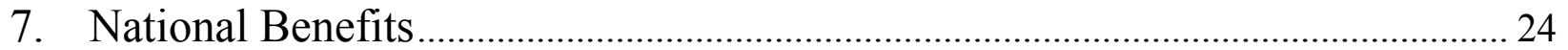

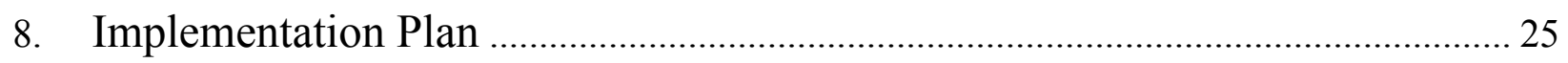

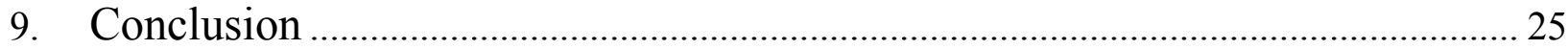




\section{$\underline{\text { Figures }}$}

Figure 1. Simplified Block Flow Diagram $\quad 7$

Figure 2. 3-Dimensional AutoCAD Model Plant Layout 10

Process Flow Diagram of EBGPS Combined Cycle (11x17 foldout) end of document

Process Flow Diagram of EBGPS Fuel Cell (11x17 foldout) end of document

3-D AutoCAD Model Layout of EBGPS IGCC (11x17 foldout) end of document

\section{$\underline{\text { Tables }}$}

Table 1. Solicitation Objectives / Emery's Accomplishments 14

Table 2. Emery Gasifier power and efficiency ASPEN modeling predictions 16

Table 3. ASPEN stack gas composition and emission predictions 17

Table 4. Plant Capital Costs Compared to NGCC Costs 19

Table 5. Cost of Electricity as a Function of the Cost of Fuel in 2002 Dollars 20

\section{$\underline{\text { Acronyms }}$}

ASPEN - Advanced System for Process Engineering

ASU - Air Separation Unit

CFD - Computational Fluid Dynamic model

COE - Cost of electricity

dRDF - Densified Refuse Derived Fuel

EBGPS - Emery Biomass Gasification Power System

$\mathrm{HHV}$ - High heating value

HRSG - Heat Recovery Steam Generator

GE - General Electric

IGCC - Integrated Gasification Combined Cycle

IGFC - Integrated Gasification Fuel Cell

INEEL - Idaho National Engineering and Environmental Laboratory

IRR - Internal Rate of Return

KWe - Kilowatts electric

KWh - Kilowatt-hour

MWe - Megawatts electric

MS - Microsoft

NGCC - Natural Gas Combined Cycle

RDF - Refuse Derived Fuel

R\&D - Research and Development

SPSA - Southeastern Public Service Authority

1-D - One Dimensional 


\begin{abstract}
Emery Recycling Corporation (now Emery Energy Company, LLC) evaluated the technical and economical feasibility of the Emery Biomass Gasification Power System (EBGPS). The gasifier technology is owned and being developed by Emery. The Emery Gasifier for this project was an oxygen-blown, pressurized, non-slagging gasification process that novelly integrates both fixedbed and entrained-flow gasification processes into a single vessel. This unique internal geometry of the gasifier vessel will allow for tar and oil destruction within the gasifier. Additionally, the use of novel syngas cleaning processes using sorbents is proposed with the potential to displace traditional amine-based and other syngas cleaning processes. The work scope within this project included: one-dimensional gasifier modeling, overall plant process modeling (ASPEN), feedstock assessment, additional analyses on the proposed syngas cleaning process, plant cost estimating, and, market analysis to determine overall feasibility and applicability of the technology for further development and commercial deployment opportunities. Additionally, the project included the development of a detailed technology development roadmap necessary to commercialize the Emery Gasification technology. Process modeling was used to evaluate both combined cycle and solid oxide fuel cell power configurations. Ten (10) cases were evaluated in an ASPEN model wherein nine (9) cases were IGCC configurations with fuel-toelectricity efficiencies ranging from $38-42 \%$ and one (1) case was an IGFC solid oxide case where $53.5 \%$ overall plant efficiency was projected. The cost of electricity was determined to be very competitive at scales from 35-71 MWe. Market analysis of feedstock availability showed numerous market opportunities for commercial deployment of the technology with modular capabilities for various plant sizes based on feedstock availability and power demand.
\end{abstract}




\section{Executive Summary}

This report and its discussion of results are based on Emery's work conducted under U.S. DOE contract DE-FC26-01NT41351 in response to U.S. DOE solicitation \# DE-PS26-01NT41130 entitled: "Biomass Research and Development: Advanced Biomass Power Generation Technologies."

Emery evaluated the feasibility of its technology for use with biomass feedstocks for power generation applications. Our base-case used 1140 tons/day of dRDF as fuel necessary to supply syngas quantities sufficient to power the GE MS6001B gas turbine combined with a steam cycle system generating at total $71 \mathrm{MWe}$ net to the grid. In the base-case, the fuel-to-electricity efficiency was projected to be $40.8 \%$. Additionally, Emery conducted process modeling to simulate the use of stationary solid oxide fuel cells. The IGFC case projected that $53.5 \%$ fuel-toelectricity efficiency could be obtained. Capital costs for the first demonstration plant were estimated to be $1878 \$ / \mathrm{kW}$ and $1572 \$ / \mathrm{kW}$ for follow-on plants. The cost of electricity (COE) was determined to be very competitive at $4.4 \mathrm{cents} / \mathrm{Kwh}$ at the $71 \mathrm{MWe}$ scale and $4.6 \mathrm{cents}$ at the $35 \mathrm{MWe}$ scale assuming the cost of $\$ 10 /$ ton for fuel and a project IRR of $12 \%$.

Principal project tasks included: gasifier modeling; feedstock assessment and availability; analysis on Emery's multi-pollutant control process for synthesis gas (syngas) cleaning; preliminary design, configuration and lay-outs of the whole plant; economic analysis of capital costs, operating costs and the resulting costs of electricity as a function of the cost of fuel; and, the creation of a technology development roadmap necessary to support commercialization.

Emery's gasifier technology takes advantage of well-known gasification processes (fixed-bed and entrained-flow) but combines these processes in a unique geometry within the gasifier. The Emery vessel combines a dual-staged, fixed-bed gasification process with entrained-flow sections necessary for tar and oil destruction (and/or additional feeding of alternative fuels including pulverized coal or slurried feedstocks). This configuration ensures the destruction of tars and oils and supports novel downstream syngas cleaning processes that contribute to lowering the capital and O\&M costs of IGCC plants. This will prevent the need for a tar and oil quench system immediately downstream of the gasifier and allow for high temperature heat/steam recovery from the raw syngas without fouling of the superheater and boiler tubes that would result with tar and oil carryover. The fixed-bed configuration was demonstrated, in part, at Emery's 25-ton/day pilot plant in central Utah. Additional design advancements were made to the gasifier during this cooperative agreement that will enhance gasifier operations and ensure desired performance characteristics at commercial scales.

\subsection{Gasifier Modeling}

Combustion Resources, LLC was subcontracted to conduct one-dimensional modeling of our gasifier system on biomass fuels. The overall objective of this task was to develop and apply a one-dimensional model of the Emery Gasification process. Data derived from this modeling was used to modify gasifier geometry, but was not sufficient to provide to the ASPEN model for the Gasifier block. This resulted in determination for the need of a more complex, threedimensional, integrated gasifier model, capable of representing the Emery Gasifier in more 
detail. The development of such a model is outlined in Phase I of the Technology Development Roadmap.

\subsection{ASPEN Modeling}

The Idaho National Engineering and Environmental Laboratory (INEEL) conducted ASPEN modeling to determine overall plant efficiencies for both combined cycle power generation schemes as well as a solid oxide fuel cell scheme. The ASPEN model was able to simulate different feedstock inputs and changes in oxygen and steam inputs to project impacts on overall plant efficiency. ASPEN modeling was also used to determine projected plant emissions. Due to the simplicity of the 1-D gasifier model discussed above, ASPEN was required to use equilibrium calculations to determine syngas compositions from the gasifier. GE Power Systems supported the ASPEN modeling effort by conducting their own simulations of the combined cycle system. GE's results were calibrated into the ASPEN process model.

\subsection{Feedstock Assessment}

Emery conducted a feedstock assessment and cost analysis of preparing RDF fuels from MSW necessary to support the 71MWe power plant. It was conservatively determined that the municipal solid waste of roughly one (1) million people is required to supply enough fuel for the $71 \mathrm{MWe}$ size plant. However, this number can fluctuate depending on the per capita waste produced and the characteristics of that waste. Based on average national tipping fees, and the capital and O\&M costs of a processing plant to convert MSW to RDF, \$10/ton was determined to represent real world RDF costs. Emery also conducted a general availability assessment of agricultural-based biomass feedstocks, their domestic distribution and availability based on certain price points. In general, agricultural derived biomass feedstocks are more expensive and only become readily available at $\$ 30 /$ ton and above.

\subsection{Conceptual Plant Design}

Emery's conceptual plant configuration consists of the following basic elements: Air Separation Plant; Fuel drying process; Fuel densification (cubing) process; Fuel feeders (lock hoppers); 3 Emery Gasifiers (includes one spare); Hot cyclone(s) for particulate removal; Superheater/Boiler for steam recovery and syngas cooling; Regenerator for adjusting syngas temperature; Baghouse/Filter Media for bulk syngas cleaning; Quench tower for final chloride removal; Packed iron oxide tower for syngas polishing; Gas turbine (with HRSG) and generator; Steam turbine and generator; and, transformers and grid interconnection.

Emery's primary efforts were spent conducting plant design, layout and preliminary engineering. Additionally, Emery did significant design and engineering work on the gasifier vessel and syngas cleaning process. Emery designed and laid out all the necessary plant equipment in 3D using AutoCAD. This allowed us to view the plant as it was designed and conduct material takeoffs to arrive at capital costs. Parallel with INEEL's ASPEN process model, Emery developed and maintained our own heat and mass balance model. This model was calibrated with INEEL's to ensure that we had a common understanding and an internal tool to evaluate variations in plant 
configuration and inputs into the gasifier. Emery's model is based in MS Excel and is linked to a detailed economic/financial model used for economic evaluation of the system. The plant uses 2 gasifiers that each process 570 tons/day of fuel. An additional spare gasifier was also included to ensure high plant availability during gasifier maintenance periods.

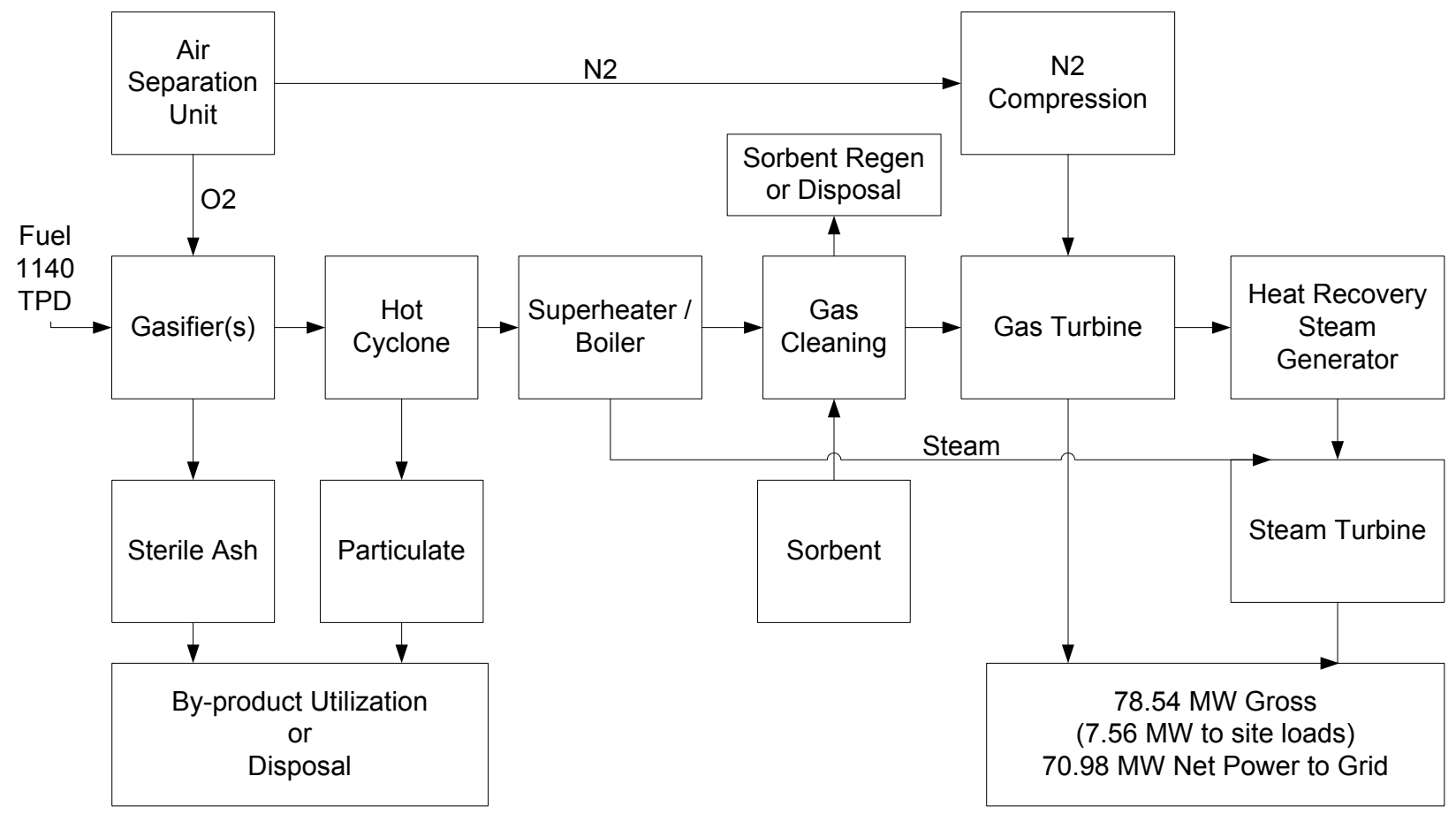

Figure 1. Simplified Block Flow Diagram

\subsection{Economic and Financial Analysis}

Capital costs for the plant were determined by using both vendor quotes and by estimating methodology based on current industry standards for recommended good practice ( $c f$ Plant Design and Economics for Chemical Engineers, Peters and Timmerhaus, $4^{\text {th }}$ Ed., McGraw-Hill@ 1991). Capital costs for the first commercial demonstration plant were determined to be $\$ 1,878 / \mathrm{kw}$. Follow-on commercial plants are expected to drop to $\$ 1,572 / \mathrm{kw}$. The cost of electricity was determined to be $4.4 \mathrm{cents} / \mathrm{kwh}$ is competitive against NGCC paying $\sim$ 2.83/MMBtu for natural gas and generating power at 4.4 cents/kwh when built at similar scales.

\subsection{Technology Development Roadmap}

Based on information gleaned during the project, Emery was able to develop a detailed technology development roadmap that will allow sequential development of the technology. The technology development plan consists of 5 phases including: Phase I - Integrated gasifier model 
development; Phase II - Component Testing; Phase III - Integrated Mock-up of gasifier; Phase IV - Design, construct and operate a pilot plant (30 - 100 tons/day); Phase V - Economic analysis and evaluation of data for scaled-up projects.

\section{Process Overview}

\subsection{Technology Background}

Emery's gasifier technology evolved from earlier work at our 25-ton/day pilot plant in central Utah. Our prototype pilot plant was designed as a 25-ton/day air-blown, fixed-bed system with both downdraft and updraft gasification processes in one vessel. Emery gasified up to 16tons/day of whole scrap passenger tires per day. The throughput was not limited by the vessel size, but rather by our custom feed system used to feed whole tires into the vessel. Certain novelties identified at the pilot plant included extremely low tar and oil carryover in the raw syngas and novel methods of controlling sulfur species in the syngas. After having accumulated over 2100 hours of operational testing at our pilot plant between the period 1996 to 1998, Emery then developed additional design advances in order for larger throughputs to be accomplished for commercial application of biomass and coal feedstocks.

Engineering and design work from 1999 up to the time we submitted our proposal to U.S. DOE in June of 2001, resulted in additional improvements to the gasifier that would allow higher feedstock throughputs necessary for commercial operations while still demonstrating the advantages of tar and oil destruction within the gasifier and additional development of our syngas cleaning process to remove gaseous phase pollutants.

Work conducted under this Cooperative Agreement with the U.S. DOE allowed Emery to make additional design changes to the internal gasifier geometry to ensure that performance characteristics could be met. Additionally, increased fuel flexibility resulted along with other beneficial features that are described in more detail below. Emery has secured three patents related to gasification prior to our project award, and had filed one additional utility patent during our cooperative agreement that was a result of earlier design work. During the Cooperative Agreement, Emery made additional design changes to the gasifier internals that will result in additional patent efforts.

\subsection{Gasifier Technology Overview}

The following provides and overview of the Emery technology necessary to distinguish the technology from other gasification processes that are used for both biomass and coal gasification. Benefits anticipated from the Emery Gasification process include: complete tar and oil destruction within the gasifier (preventing the need for downstream tar crackers); greater fuel flexibility; novel processes for controlling and removing gaseous phase pollutants from the syngas; lower capital and O\&M costs. A detailed illustration of the gasifier is included in 
Appendix A (All materials in Appendix A are confidential and intended for viewing only by the U.S. Department of Energy).

Tar and Oil destruction within the gasifier offers many benefits to gasification-based projects. Biomass fuels are known to have a very high volatile-to-fixed carbon ratio and hence typically produce significant quantities of tars and oils, requiring additional process equipment necessary to handle or mitigate them. In other fixed-bed gasifiers, tars and oils must either be re-injected into the gasifier (as is done in the British Gas/Lurgi slagging gasifier) or in the case of Lurgi Dry Ash gasifier, where larger volumes of tars and oils are present, must be removed from the syngas stream and upgraded to various chemical products. Control of tars and oils post-gasifier typically requires additional downstream equipment necessary to destroy tars and oils as well as immediate syngas quenching, thus preventing high temperature heat/steam recovery, and preventing higher overall plant efficiencies. By designing the vessel to destroy all tars and oils within the gasifier, we are able to avoid additional capital and operating costs. Additionally, we are able to recover high temperature heat/steam immediately downstream of the gasifier, which improves overall plant efficiency and generates an additional source of high-grade steam for use by industrial process plants or for use in the steam bottoming cycle of an IGCC.

Fuel flexibility in the Emery system is enhanced by combining both fixed-bed and entrainedflow gasification processes. The fixed-bed section gasifies the coarse fuels (most biomass fuels) while the entrained-flow sections allow for the gasification of fines or liquid fuels (i.e. pulverized coal, liquid slurried fuels including waste oils and/or municipal or industrial sludges). Fuelflexibility is very attractive to project developers who are primarily concerned with the need to achieve certain economies of scale. Fuel flexibility also can increase technology market penetration by coordinating the availability of 2 or 3 feedstocks necessary to achieve the desired plant size.

Control of pollutants from the plant is accomplished by using a novel sorbent that is pre-coated onto a baghouse or other filter media, wherein the syngas passes through for bulk contaminant removal. Based on experience at our pilot plant and on a literature review of similar downstream processes, Emery made estimates as to the efficiency of adsorption. These adsorption efficiencies were used as inputs into the ASPEN model in order to predict final emissions from the plant. Additional development is planned to verify anticipated efficiencies and to validate process claims in this area. Emery's process has the potential to significantly reduce the costs of syngas cleaning, hence lowering the capital and O\&M costs of gasification plants. Lowering the capital and O\&M costs of gasification plants is essential to ensure broad market penetration into the power, fuels and chemical sectors.

\subsection{Design Basis}

As discussed above, the Emery gasifier technology proposed to DOE was based on both our development successes at our 25-ton/day pilot plant as well as on additional design development and engineering that took place after testing at our pilot plant. While the internal vessel geometry is novel, the Emery design uses well-known gasification principles from both fixedbed and entrained-flow processes, hence mitigating the risk of new technology. Downstream syngas cleaning processes were projected based on experience gained at our pilot plant and from 
additional information contained in literature. With the exception of the syngas cleaning step and the methodology used for tar and oil destruction, the overall plant configuration is similar to other IGCC configurations.

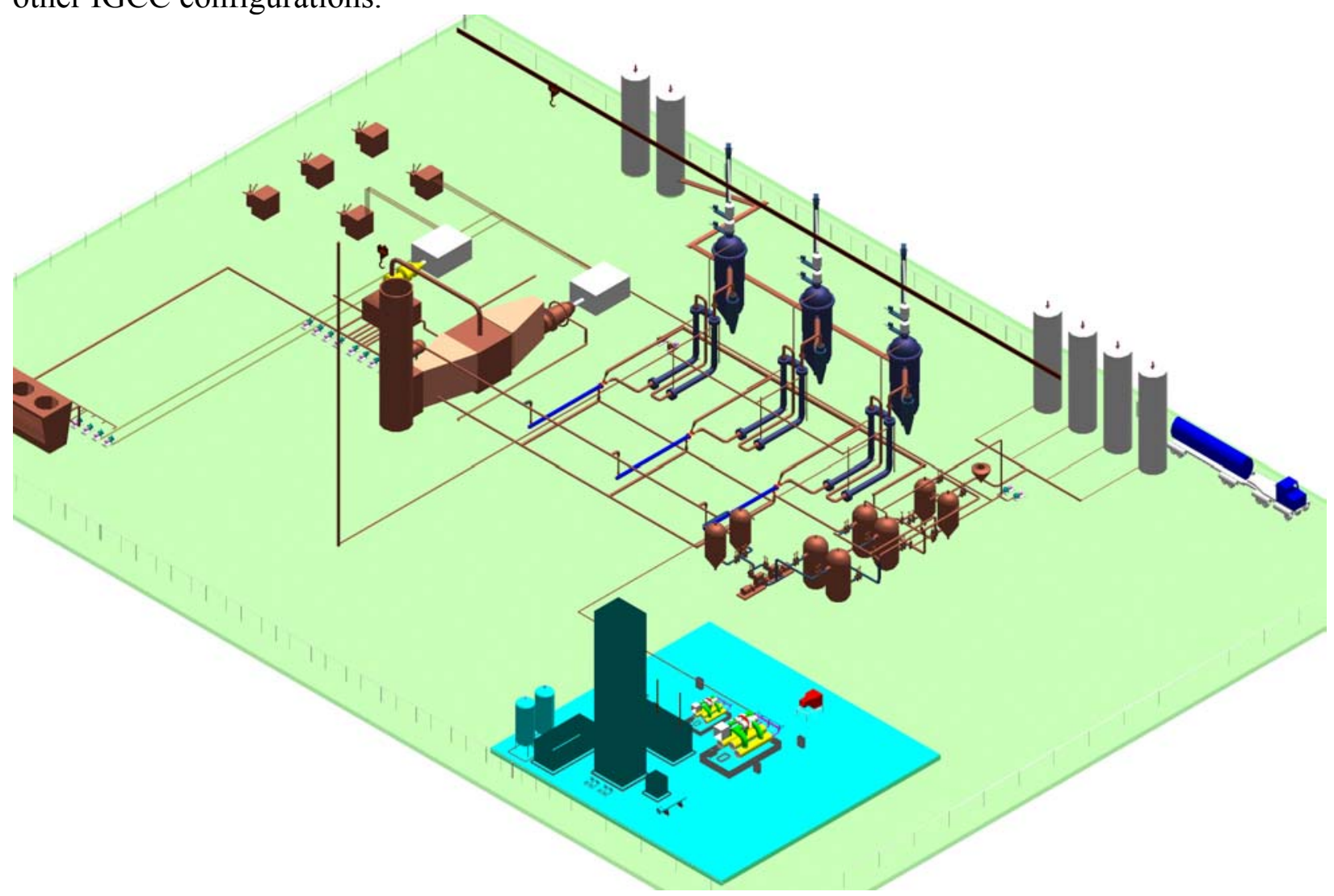

Figure 2. 3-Dimensional AutoCAD Model Plant Layout

\subsection{Process Description (see Process Flow Diagram at end of Report)}

The following describes the general process of our base-case plant, while the detailed description of the Gasifier geometry and functions are in Appendix A.

\subsubsection{Fuel Preparation}

1295 short tons/day of wet RDF fuel (30\% moisture) sized approximately at 2" minus, is delivered to the site and is dried to $12 \%$ moisture in a fuel drying system that uses waste heat from the flue gas exiting the gas turbine and waste heat from the gasifier shell. 1034 Metric tons (1140 short tons/day) of $12 \%$ moisture fuel is then densified before being sent to a dual vertical lock hopper system that allows the fuel to be pressurized to match the gasifier pressure conditions (400 psig) prior to feeding.

\subsubsection{Gasification Process}


The fuel enters the upper section of the gasifier where fuel drying, devolitization and pyrolysis take place. Tars and oils are carried into the entrained flow section for destruction and gasification. Devolitized fuel (char) proceeds to the lower section of the gasifier as it gasifies. Sterile ash exits the bottom of the gasifier in a 'dry ash' mode (i.e. non-slagging mode). Depending on the fuel and the availability of fixed-carbon in the lower bed, the gasifier can be operated in slagging mode as an alternative if desired. However, dry ash mode is preferred for longevity of ceramic and lower O\&M costs. A cryogenic air separation plant quoted by Linde Process Plants is used to provide $95 \%$ pure oxygen to the two gasifiers at a rate of $12,366 \mathrm{~kg} / \mathrm{hr}$ $(27,263 \mathrm{lbs} / \mathrm{hr}$ or 13.6 short tons/hr) - one half for each gasifier. Steam injection was not used in the base case, but water injection was. Water injection into the lower fixed-bed section was injected at a temperature of $37.8^{\circ} \mathrm{C}\left(100^{\circ} \mathrm{F}\right)$ and at a rate of $5,434 \mathrm{~kg} / \mathrm{hr}(2,470 \mathrm{lbs} / \mathrm{hr})$.

\subsubsection{Heat Recovery / Steam Generation from Syngas}

Tar and oil free syngas exit the gasifier at $732^{\circ} \mathrm{C}\left(1350^{\circ} \mathrm{F}\right)$ and pass first through a hot cyclone for primary particulate removal. The ceramic-lined hot cyclone has a water jacket to maintain temperatures in the hot cyclone and reduce thermal wear on the refractory and hot water is generated and sent to the condenser near the steam turbine. The slightly cooler syngas exits the hot cyclone at $685^{\circ} \mathrm{C}\left(1265^{\circ} \mathrm{F}\right)$ then goes through the primary heat recovery steam generating system that recovers the heat via a superheater/boiler combination. Steam generated from the superheater exits at $485^{\circ} \mathrm{C}\left(905^{\circ} \mathrm{F}\right)$ and is sent to the steam turbine along with steam at identical conditions derived from the waste heat boiler adjacent to the gas turbine. Syngas exits the superheater $599^{\circ} \mathrm{C}\left(1110^{\circ} \mathrm{F}\right)$ where it is fed to the boiler necessary to provide the initial temperature raising of the boiler feedwater, which is delivered from the waste heat boiler.

\subsubsection{Syngas Cleaning}

Syngas exits the boiler at $265^{\circ} \mathrm{C}\left(509^{\circ} \mathrm{F}\right)$ and enters a regenerator that further cools the syngas to $160^{\circ} \mathrm{C}\left(320^{\circ} \mathrm{F}\right)$ prior to feeding the syngas to the primary baghouse/filter media where bulk removal of gaseous phase pollutants is accomplished. The baghouse is pre-coated with proprietary sorbent necessary to provide bulk removal of pollutants. After the syngas passes through the baghouse, it then goes to a quench tower for additional cooling and spray down of any chlorides not captured in the baghouse. Cooled Syngas exits the quench vessel at $37.8^{\circ} \mathrm{C}$ $\left(100^{\circ} \mathrm{F}\right)$ in order to be fed to a vessel of packed iron oxide called SulfaTreat used to remove any remaining trace sulfur species (if sulfur is in the fuel).

\subsubsection{Power Generation - Gas Turbine}

Prior to combustion in the gas turbine, the clean syngas passes back through the regenerator in a countercurrent fashion and at a slightly higher pressure than the raw syngas to prevent potential contamination of the clean syngas if a leak were to occur. The clean syngas is raised to $176^{\circ} \mathrm{C}$ $\left(350^{\circ} \mathrm{F}\right)$ to match the desired inlet temperatures for the GE MS6001B gas turbine as specified by GE Power Systems. The combustion turbine generates 48.3 megawatts. 


\subsubsection{Power Generation - Steam Turbine}

Steam flows from the superheater at $16,250 \mathrm{~kg} / \mathrm{hr}(35,825 \mathrm{lbs} / \mathrm{hr})$ and steam flows from the waste heat boiler at $107,710 \mathrm{~kg} / \mathrm{hr}(237,460 \mathrm{lbs} / \mathrm{hr})$ adjacent to the gas turbine are joined to power a $\mathrm{GE}$ STAG 206FA Steam Turbine/Generator producing an additional 30.2 megawatts.

\subsubsection{Parasitic Site Loads}

Parasitic site power requirements are dominated by the Air Separation Unit requiring approximately 6.4MWe of power including nitrogen compression for diluent to the gas turbine. An additional 1.1MWe is required for fuel densification and miscellaneous pumps and blowers.

\subsubsection{Plant Efficiency}

The resulting net plant efficiency for the base case was $40.8 \%$ fuel-to-electricity. Gross power output totaled 78.54MW. Parasitic site loads required 7.56MW. Hence, net power output was 70.98MW. Additional cases and their net efficiencies derived from the ASPEN model are shown in Table 2.

\section{Process Modeling}

Overall process modeling of the Emery plant was conducted by both INEEL and Emery. INEEL used the ASPEN Plus program for modeling process plants and Emery used MS EXCEL to maintain our own internal process model and heat/mass balances. Throughout the project, Emery and INEEL calibrated the two models. Only minor differences in overall plant efficiencies resulted. For example, on the base-case, INEEL showed an overall plant efficiency of $40.8 \%$ while Emery's model showed $39.7 \%$. This difference was primarily a result of the differences in the way ASPEN calculates the HHV of the fuel. ASPEN's calculation for HHV for the dRDF fuel was slightly higher than Emery's calculation. This resulted in the difference between INEEL's base case that required 1140 tons/day of fuel and Emery's model that shows 1210 tons/day of fuel is required. This difference is derived from the method by which ASPEN calculates the HHV of fuel using methodology from the Institute of Gas Technology.

Emery's internal process model was linked to a detailed economic and financial model that allowed us to view a financial pro-forma of the plant while adjusting many financial input variables and/or feedstocks. Additionally, the economic and financial model provided a tool necessary to conduct sensitivity analyses of capital costs, fuel costs and financing structures and associated impacts on the COE. The process flow diagram and piping and instrumentation diagram included herein show data resulting from Emery's MS EXCEL model. These were selected for inclusion for their readability. ASPEN model runs and associated detailed process flow sheets are included in Appendix B (INEEL's Final Report). 
Process modeling used ambient conditions typical of Portsmouth, Virginia where the SPSA RDF facility is located. Details of ambient conditions are contained in Appendix A. Details of the ASPEN process model are contained in Appendix B, INEEL's final report.

\subsection{Gasifier Model}

Combustion Resources, LLC was subcontracted to conduct one-dimensional modeling of our gasifier system on biomass fuels. Combustion Resources sought the expertise of Dr. Larry Baxter at Brigham Young University to conduct modeling of the Emery process because of his experience with biomass fuels. The overall objective of this task was to develop and apply a 1-D model of the Emery Gasification process. The major characteristics of the 1-D gasifier model developed for this project included: (1) finite-difference solution scheme used; (2) mass and energy balances used as basis for the model; (3) gas phase and heterogeneous reactions modeled; (4) first-order devolatilization kinetics used for biomass fuels; (5) diffusion-limited coal char kinetics used for heterogeneous reactions; (6) moisture evaporation and condensation reactions; (7) effects of buoyancy-driven recirculation zone; (8) temperature equilibrium between gas and solid assumed; (9) product gas composition based on local stoichiometry and temperature.

Key results of the application of the 1-D gasifier model are summarized below, and more detailed results of the gasifier modeling are provided in Appendix C. Simulations were performed to model multiple injection locations and different gasifier feed rates, and to investigate the effects of a buoyancy driven flow field on gasifier performance and operation. Calculations with the 1-D gasifier model showed that the fuel heat up and devolitization occurred very rapidly, and that devolatilization was essentially complete within the top of the gasifier. Initial results of these simulations provided insights into possible gasifier design modifications, and also indicated the need for a more detailed gasifier model to help answer these design questions. Simulations with the 1-D gasifier model also showed the need for a multidimensional gasifier model to better describe the flow and reaction processes occurring in the Emery Gasifier. Simulations were also performed for a downdraft biomass gasifier for which published results of gasifier operation were available. Comparison of the model predictions with published results for this gasifier showed qualitative agreement with the published results. These comparisons included how temperature and compositions in the gasifier varied as a function of particle size and fuel feedrate.

\subsection{Aspen Model}

INEEL's principal task was to develop and run the ASPEN model to represent the EBGPS on various biomass fuels, one coal fuel (Utah bituminous) and one case where RDF and coal were blended. A detailed discussion of the ASPEN model work is contained in the report from INEEL in Appendix B as a separate volume. The goal of the ASPEN model was to be able to predict overall plant efficiency and emissions. Vendor input was provided for both the Air Separation Unit (Linde Gas) and the Gas/Steam Turbine (GE Power Systems). Emery provided much of the data and equipment used for the ASPEN modeling including: fuel drying system; gasifier configuration and syngas outlet temperatures; heat recovery and steam generation 
equipment; gas cleaning efficiencies with high/low recovery estimates based on experience at pilot plant and additional literature review. The solid oxide fuel cell case was based on information gleaned from the $5^{\text {th }}$ Edition of the Fuel Cell handbook. In all, nine (9) IGCC cases were run and one (1) IGFC case was run including: three cases on dRDF, one case on Hogwood, one case on Switchgrass, three cases on Utah coal and one case using a coal/dRDF blend at $35 \% / 65 \%$ ratio based on a heating value of fuel input basis. The $10^{\text {th }}$ case was the solid oxide fuel cell case using the same $\mathrm{dRDF}$ feed rates as our base case. Overall fuel-to-electricity plant efficiencies for the IGCC cases ranged from $38.5 \%$ to $42.3 \%$, with our base-case at $40.8 \%$. The solid oxide IGFC case predicted $53.5 \%$ net plant efficiency.

\section{Technical, Environmental and Economic Performance}

The original solicitation provided the technical and economic goals and framework for which a technology should achieve, in order to represent advancements in the state of the art. Table 1 lists the solicitation objectives along with results from Emery's work.

\section{Table 1. Solicitation Objectives / Emery's Accomplishments}

\begin{tabular}{|c|c|}
\hline Solicitation Objectives & Emery's Accomplishments \\
\hline $\begin{array}{l}\text { 1. Baseload power generation with a nominal } \\
\text { annual capacity factor of } 85 \%\end{array}$ & $\begin{array}{l}\text { 1. Emery's system, using } 3 \text { gasifiers (including one } \\
\text { spare) is designed to be a base load plant with } \\
\text { annual capacity factor of greater than } 90 \%\end{array}$ \\
\hline $\begin{array}{l}\text { 2. Cost of power should be competitive in individua } \\
\text { circumstances }\end{array}$ & $\begin{array}{l}\text { 2. The cost of power determined for the EBGPS } \\
\text { would be not only be competitive on individual } \\
\text { circumstances but also on a national scale. Projects } \\
\text { below } 25 \mathrm{MWe} \text { would need to be competitive in } \\
\text { individual circumstances. }\end{array}$ \\
\hline $\begin{array}{l}\text { 3. Efficiency for plants smaller than } 100 \mathrm{MWe} \\
\text { should achieve at least } 35 \% \text { with the clear potential } \\
\text { to evolve to } 45 \% \text { efficiency }\end{array}$ & $\begin{array}{l}\text { 3. Our base-case IGCC } 71 \mathrm{MWe} \text { plant had a fuel-to- } \\
\text { electric efficiency of } 40.8 \% \text { and our IGFC } 93 \mathrm{MWe} \\
\text { plant had an efficiency of } 53.5 \% \text { when stationary fuel } \\
\text { cells become available }\end{array}$ \\
\hline $\begin{array}{l}\text { 4. Airborne Emissions shall not be greater than } \\
\text { one-half the amount allowed by current New Source } \\
\text { Performance Standards for coal-fired electric power } \\
\text { generation, or local regulations where system } \\
\text { deployment is being considered }\end{array}$ & $\begin{array}{l}\text { 4. Based on data obtained at Emery's pilot plant and } \\
\text { additional information gleaned from literature, inputs } \\
\text { to the ASPEN model on syngas cleaning } \\
\text { methodology and efficiencies, resulted in meeting } \\
\text { this criteria }\end{array}$ \\
\hline $\begin{array}{l}\text { 5. Solid wastes must be benign with regards to } \\
\text { disposal. Preference will be given to concepts in } \\
\text { which solid waste generation is minimized through } \\
\text { the production of usable by-products }\end{array}$ & $\begin{array}{l}\text { 5. Bottom ash from the gasifier and particulate from } \\
\text { the Hot Cyclone are benign and may represent by- } \\
\text { product sales potential. Characteristics of spent } \\
\text { sorbent used to capture gaseous phase pollutants } \\
\text { must be evaluated in later phases }\end{array}$ \\
\hline $\begin{array}{l}\text { 6. Acceptable fuels: The ultimate goal is the } \\
\text { development of advanced power generation } \\
\text { systems in which biomass is the predominant fuel } \\
\text { (i.e. }>95 \% \text { of fuel input) }\end{array}$ & $\begin{array}{l}\text { 6. Emery's cases that relied solely on biomass fuels } \\
\text { were shown to be very competitive. Emery did } \\
\text { evaluate a co-gasification alternative with coal as } \\
\text { allowed by the solicitation up to } 35 \% \text { of heat input } \\
\text { into the system. Emery views co-gasification } \\
\text { schemes as very favorable for project developers } \\
\text { wishing to mitigate long-term fuel risk and/or seeking }\end{array}$ \\
\hline
\end{tabular}




\begin{tabular}{|c|c|}
\hline & $\begin{array}{l}\text { larger project scales that can be obtained by } \\
\text { including coal and/or other feedstocks }\end{array}$ \\
\hline $\begin{array}{l}\text { 7. Biomass fuel flexibility: Given the tremendous } \\
\text { variation in the compositional characteristics across } \\
\text { the many biomass families (e.g. woods, herbaceous } \\
\text { crops, manures, municipal solid waste, etc.) it is } \\
\text { recognized that a single power system may not be } \\
\text { appropriate to utilize all biomass. Accordingly, the } \\
\text { R\&D proposed and performed as a result of this } \\
\text { solicitation may address a specific but significant } \\
\text { subset of available biomass }\end{array}$ & $\begin{array}{l}\text { 7. Emery believes that its unique gasifier } \\
\text { configuration will make it one of the most fuel-flexible } \\
\text { gasification processes available. In order to achieve } \\
\text { wide-scale national commercial deployment, Emery } \\
\text { primarily evaluated the use of dRDF as a fuel to the } \\
\text { gasifier, representing a significant subset of biomass } \\
\text { fuel availability easily calculable with human } \\
\text { populations. However, a significant amount of } \\
\text { agricultural biomass feedstocks also become readily } \\
\text { available at } \$ 30 / \text { ton and higher }\end{array}$ \\
\hline $\begin{array}{l}\text { 8. Performance Attributes: Preference will be given } \\
\text { to concepts that allow load-following with minimal } \\
\text { degradation of efficiency, and that are amenable to } \\
\text { construction using factory assembled modular } \\
\text { components based upon standard designs }\end{array}$ & $\begin{array}{l}\text { 8. While Emery anticipates a high turn-down ratio } \\
\text { within the gasifier, Gas Turbines do not perform well } \\
\text { when gas flows are significantly reduced. Load } \\
\text { following capability requires further evaluation. The } \\
\text { modularity of the system will allow for a range of } \\
\text { plant sizes to be built. Emery's gasifier has some } \\
\text { unique internal geometries that will require initial } \\
\text { custom engineering/fabrication }\end{array}$ \\
\hline
\end{tabular}

\subsection{Technical Performance}

Technical performance was determined by using both INEEL's ASPEN Plus process modeling program as well as empirical process modeling conducted by Emery in MS EXCEL. The unique internal geometry of the Emery gasifier coupled with the improvements made during this cooperative agreement, continue to build the case that the Emery gasifier represents a significant advancement in biomass gasification. This is due primarily to design that ensures the destruction of all tars and oils within the gasifier, therefore preventing the need for tar and oil clean up systems or the fouling of downstream equipment caused by tars and oils. It also allows for high temperature steam recovery immediately downstream of the gasifier. Additionally, the design of the gasifier to operate at elevated pressures, allows the gasifier to be matched to the downstream gas turbine requirements without the need for syngas compression. While limited gasifier modeling was conducted using a one-dimensional model, we determined that a much more complex and detailed computer-modeling program is necessary to accurately predict operational characteristics and validate fuel conversions and other process claims within the gasifier. However, operational experience gained at our 25-ton pilot plant in central Utah, represent experience gained by Emery in operating such a gasifier, in part, and provided initial design data necessary to design the current system.

Other benefits anticipated include greater control of the $\mathrm{H}_{2}: \mathrm{CO}$ ratio of the syngas. This will benefit downstream syngas conversion processes for fuels and chemicals production. Additional design changes made to the gasifier during the coarse of this cooperative agreement will allow for co-feeding of biomass with pulverized coal into the gasifier. This advantage may allow for greater market use of the gasifier where both fuels are sought or where there is an 
inadequate supply of biomass fuels. These anticipated technical benefits will be modeled during the next phase of technology development. Technical performance is summarized in Table 2.

Table 2. Emery Gasifier power and efficiency ASPEN modeling predictions

\begin{tabular}{|c|c|c|c|c|c|c|c|c|c|c|}
\hline & Case 1 & Case 2 & Case 3 & Case 4 & Case 5 & Case 6 & Case 7 & Case 8 & Case 9 & Case 10 \\
\hline \multicolumn{11}{|l|}{ Fuel } \\
\hline RDF Feed Rate - $12 \%$ moisture (ton/dy) & 1140 & 1170 & - & - & - & - & - & - & 720 & 1140 \\
\hline RDF Feed Rate - $18.8 \%$ moisture (ton/dy) & - & - & 1280 & - & - & - & - & - & - & - \\
\hline HogWood Feed Rate - $12 \%$ moisture (ton/dy) & - & - & - & 1000 & - & - & - & - & - & - \\
\hline SwitchGrass Feed Rate (ton/dy) & - & - & - & - & 1080 & - & - & - & - & - \\
\hline Utah Coal Feed Rate (ton/dy) & - & - & - & - & - & 575 & 610 & 575 & 211 & - \\
\hline \multicolumn{11}{|l|}{ Gasifier } \\
\hline Gasifier Outlet Temperature $\left({ }^{\circ} \mathrm{F}\right)$ & 1350 & 1350 & 1350 & 1450 & 1350 & 1550 & 1550 & 1550 & 1450 & 1350 \\
\hline Gas Equilibrium Temperature Calculation $\left({ }^{\circ} \mathrm{F}\right)$ & 1450 & 1450 & 1500 & 1550 & 1450 & 1750 & 1750 & 2250 & 1600 & 1450 \\
\hline Sorbent use ratio to fuel inputs (wt\%) & 0.6 & 1.5 & 0.6 & 0.1 & 0.07 & 1.3 & 1.3 & 1.3 & 0.8 & 0.6 \\
\hline H.P. Steam Flow to Gasifier (Ib/hr) & - & - & - & - & - & 10,000 & 63,000 & - & - & - \\
\hline Water Flow to Gasifier Bottom (lb/hr) & 2,470 & 2,535 & 2,773 & 2,167 & 2,340 & - & - & - & 1,560 & 2,470 \\
\hline $\mathrm{O}_{2}$ Requirement $(\mathrm{lb} / \mathrm{hr})$ & 27,260 & 27,430 & 32,450 & 43,640 & 32,840 & 36,870 & 42,410 & 38,560 & 32,360 & 27,260 \\
\hline \multicolumn{11}{|l|}{ Gas Turbine } \\
\hline Syngas Flow to Gas Turbine (lb/hr) & 93,310 & 93,800 & 100,610 & 107,100 & 95,900 & 83,900 & 101,100 & 80,840 & 89,420 & - \\
\hline $\mathrm{N}_{2}$ Diluent Flow (lb/hr) & 63,000 & 63,000 & 63,000 & 63,000 & 65,000 & 62,000 & 50,000 & 75,000 & 63,000 & - \\
\hline Gas Turbine Net Output $(\mathrm{kW})^{*}$ & 48,340 & 48,420 & 48,510 & 47,880 & 48,680 & 47,400 & 47,960 & 48,060 & 47,730 & - \\
\hline \multicolumn{11}{|l|}{ Steam Turbine } \\
\hline High-Pressure Steam Flow (Ib/hr) & 192,800 & 192,800 & 192,800 & 192,800 & 192,800 & 192,800 & 192,800 & 192,800 & 192,800 & 150,000 \\
\hline Low-Pressure Steam Flow $(\mathrm{lb} / \mathrm{hr})^{\star *}$ & 44,660 & 45,520 & 50,430 & 50,120 & 46,540 & 28,510 & 830 & 36,000 & 41,810 & 17,590 \\
\hline Steam Turbine Net Output (kW) & 30,200 & 30,280 & 30,630 & 30,610 & 30,350 & 29,040 & 27,040 & 29,580 & 30,010 & 22,260 \\
\hline \multicolumn{11}{|l|}{ Solid Oxide Fuel Cell / Gas Turbine Hybrid } \\
\hline Low-Pressure SOFC Output (kW) & - & - & - & - & - & - & - & - & - & 20,640 \\
\hline High-Pressure SOFC Output (kW) & - & - & - & - & - & - & - & - & - & 26,400 \\
\hline Turbine \& Expander Gross Output (kW) & - & - & - & - & - & - & - & - & - & 64,590 \\
\hline Air Compressor Power Consumption (kW) & - & - & - & - & - & - & - & - & - & 35,400 \\
\hline SOFC Hybrid Net Output (kW) & - & - & - & - & - & - & - & - & - & 76,230 \\
\hline \multicolumn{11}{|l|}{ Plant Calculations (based on HHV) } \\
\hline Net Power Generation (kW) & 70,980 & 71,090 & 70,720 & 68,370 & 70,530 & 67,490 & 65,240 & 68,060 & 69,420 & 93,100 \\
\hline Net Plant Heat Rate (BTU/kW-hr) & 8,360 & 8,566 & 8,699 & 8,717 & 8,860 & 8,134 & 8,927 & 8,066 & 8,300 & 6,374 \\
\hline Overall Plant Efficiency (\%) & 40.8 & 39.8 & 39.2 & 39.1 & 38.5 & 41.9 & 38.2 & 42.3 & 41.1 & 53.5 \\
\hline
\end{tabular}

\subsection{Environmental Performance}


Environmental performance for air emissions were modeled in ASPEN using input provided by Emery. These inputs for syngas cleaning efficiencies were derived from a combination of Emery's experience at our pilot plant, coupled with data found in literature. $\mathrm{NOx}, \mathrm{SOx}, \mathrm{HCl}, \mathrm{CO}$ and Particulate Matter were the pollutants evaluated.

\section{Table 3. ASPEN stack gas composition and emission predictions}

Case 1 Case 2 Case 3 Case 4 Case 5 Case 6 Case 7 Case 8 Case 9 Case 10

Fuel

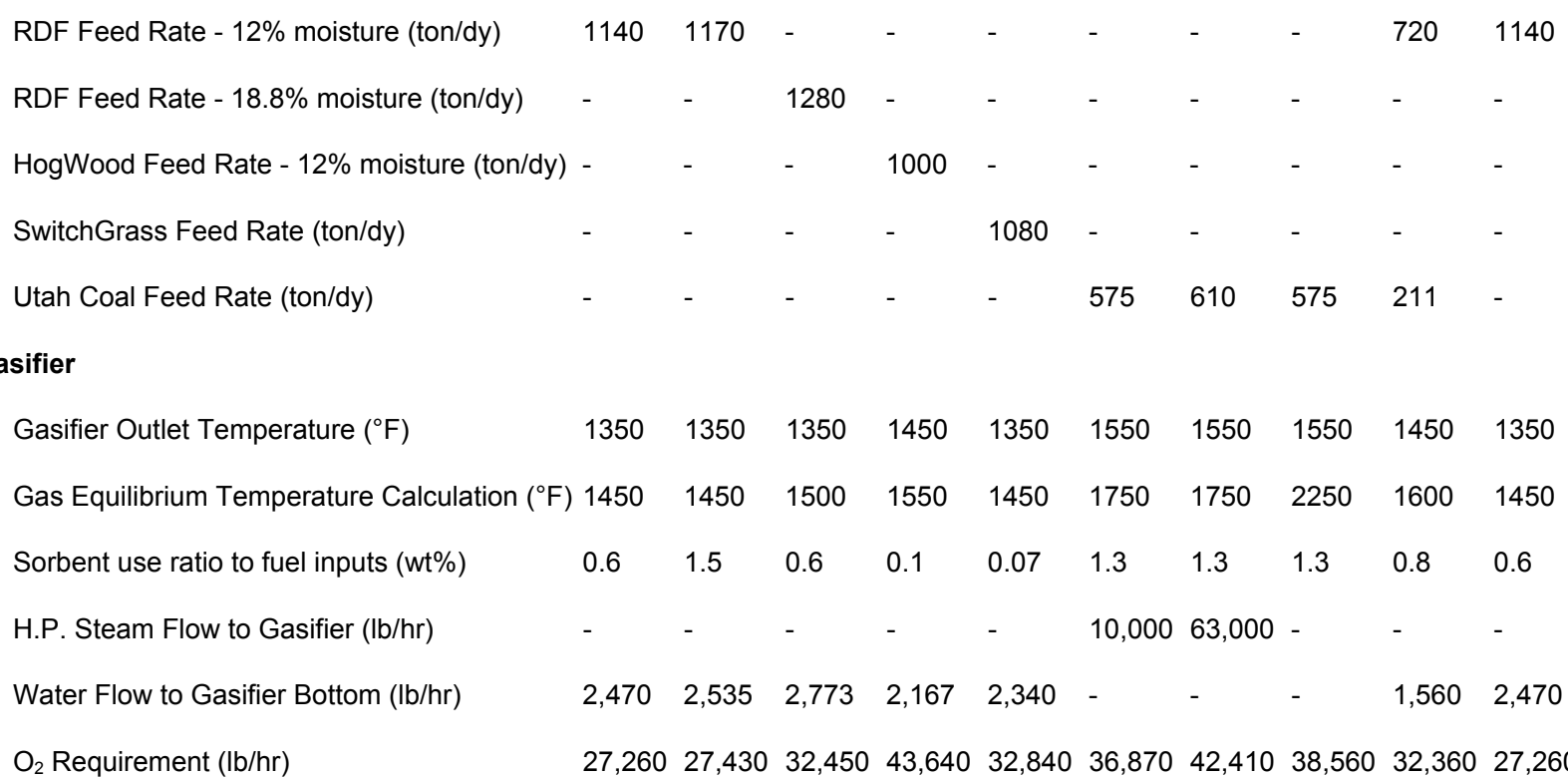

\section{Emissions}

Sulfur Sorption of Sorbent Assumed (Ib Sorbent / lb S)

$\begin{array}{llllllllll}2.0 & 5.0 & 2.0 & 2.0 & 2.0 & 2.0 & 2.0 & 2.0 & 2.0 & 2.0\end{array}$

Exhaust Rate (klb/hr)

$\begin{array}{llllllllll}1,298 & 1,299 & 1,306 & 1,312 & 1,303 & 1,288 & 1,293 & 1,298 & 1,294 & 695\end{array}$

Exhaust Composition (mol fraction)

$\begin{array}{llllllllllll}\mathrm{N}_{2} & 73.52 & 73.48 & 73.13 & 73.13 & 73.46 & 74.20 & 72.54 & 74.83 & 73.89 & 68.31 \\ \mathrm{O}_{2} & 13.62 & 13.61 & 13.66 & 13.78 & 13.53 & 14.05 & 13.85 & 14.10 & 13.92 & 9.12 \\ \mathrm{H}_{2} \mathrm{O} & 5.55 & 5.61 & 5.76 & 5.10 & 5.63 & 4.71 & 6.48 & 4.05 & 4.98 & 9.60 \\ \mathrm{CO}_{2} & 6.35 & 6.35 & 6.50 & 7.02 & 6.43 & 6.05 & 6.18 & 6.03 & 6.25 & 11.99 \\ \mathrm{Ar} & 0.94 & 0.94 & 0.94 & 0.97 & 0.95 & 0.98 & 0.95 & 0.99 & 0.96 & 0.97 \\ \mathrm{NO}_{x}, \mathrm{ppm} \text { (as NO) } & 43 & 43 & 43 & 43 & 43 & 43 & 43 & 43 & 43 & * \\ \mathrm{HCl}, \mathrm{ppb} & 71 & 71 & 58 & * * & * * & * * & * * & * * & * * & 134 \\ \mathrm{SO}_{2}, \mathrm{ppb} & 27 & 27 & 27 & * * * & * * * & 32 & 29 & 33 & 29 & 50 \\ \mathrm{CO}, \mathrm{ppb} & 54 & 54 & 49 & 45 & 54 & 54 & 47 & 55 & 52 & 14 \\ \mathrm{Hg}, \mathrm{ppb} & 1.7 & 1.7 & 1.6 & * * * * * & * * * * * & * * * * & * * * * * & * * * * * & * * * * * & 1.7\end{array}$


$\mathrm{NO}_{\mathrm{x}}$ emissions have not yet been estimated by GE for this case.

** Fuel analysis was missing chlorine concentration

*** Sulfur analysis was not available for Hogwood and Switchgrass fuels. Hence, all sulfur was assumed to be sulfate for these cases.

**** Aspen erroneously predicts all remaining mercury to condense in the quench operation. Therefore, this value represents mercury concentration immediately upstream of the quench. Note that due to dilution alone, mercury in the exhaust will be an order of magnitude lower than this value.

***** Mercury analysis was not available for all fuels modeled.

The information below summarizes the predicted emissions compared with NSPS.

NOx: (The use of dry low NOx or other systems were not evaluated during this study, and it is believed that lower NOx emissions can be achieved)

Predicted emissions $=0.81 \mathrm{lb} \mathrm{NOx} / \mathrm{MW} \mathrm{hr}$

$\mathrm{NSPS}=1.6 \mathrm{lb} \mathrm{NOx} / \mathrm{MW} \mathrm{hr}$

Predicted NSPS ratio $=0.51$

Predicted emission $=0.097 \mathrm{lb}$ NOx $/$ MMBtu RDF

$\mathrm{NSPS}=0.15 \mathrm{lb}$ NOx $/$ MMBtu

Predicted $/$ NSPS ratio $=0.65$

SOX:

Predicted Removal $=98 \%$

NSPS $=70 \%-90 \%$

Predicted emission $=0.00013 \mathrm{lb} \mathrm{SOx} /$ MMBtu RDF

$\mathrm{NSPS}=0.6-1.2 \mathrm{lb} \mathrm{SOx} / \mathrm{MMBtu}$

Predicted $/$ NSPS ratio $=0.0001-0.0002$

\section{Particulate:}

Predicted particulate $=0.00 \mathrm{lb} / \mathrm{MMBtu} \mathrm{RDF}$

$\mathrm{NSPS}=0.03 \mathrm{lb} /$ MMBtu

Predicted / NSPS ratio $=0.00$

Predicted removal $=100 \%$

NSPS $=99 \%$

Specific predictions for the bottom ash were not made, however, we do not anticipate any wastes that are not capable of being landfilled in non-hazardous landfills.

\subsection{Economic Analysis}

Emery performed a detailed economic analysis of the EBGPS in order to determine the cost of electricity anticipated from such a system. Doing so included an evaluation of likely fuel costs for RDF and other biomass feedstocks. Emery worked with SPSA to learn of plant capital costs necessary to convert MSW to RDF. This information was coupled with current O\&M costs supplied by SPSA. A review of current domestic tipping fees allowed Emery to arrive at a cost of fuel that determined the cost of electricity based on an IRR of 12\% using 70:30 debt to equity ratio. 
Emery developed and maintained a detailed financial model in MS EXCEL that was linked to the heat and mass balance and the equipment list for the plant. The capital costs were derived from a combination of vendor quotes and unit material take-offs using estimating methodology based on current industry standards for recommended good practice. Emery conducted all design of the plant in 3-D using AutoCAD. This enabled us to design and view the plant in 3-D throughout the development of the project. The 3-D model also enabled Emery to calculate all materials required for each piece of equipment.

\subsubsection{Capital and O\&M Costs}

The following table illustrates the capital and O\&M costs summary of the EBGPS based on using all new equipment. The bottom of the table shows the capital and O\&M costs of a similar sized NGCC plant to show that the EBGPS is very competitive.

Table 4. Plant Capital Costs Compared to NGCC Costs

\begin{tabular}{|c|c|}
\hline \multicolumn{2}{|l|}{ Direct Costs } \\
\hline Fuel Handling & $\$ 8,166,000$ \\
\hline Gasification Equipment & $\$ 12,679,000$ \\
\hline Air Separation \& Compression System & $\$ 13,415,000$ \\
\hline Gas Handling \& Cleanup System & $\$ 5,057,000$ \\
\hline Gas Turbine \& Steam Turbine Plant (provided by GE) & $\$ 62,219,000$ \\
\hline Balance of Plant & $\$ 2,380,000$ \\
\hline Direct Cost Total & $\$ \$ 103,916,000$ \\
\hline \multicolumn{2}{|l|}{ Indirect Costs } \\
\hline Engineering Costs & $\$ 5,724,000$ \\
\hline Home Office Costs & $\$ 2,880,000$ \\
\hline Contingency & $\$ 7,544,000$ \\
\hline Interest During Construction & $\$ 6,088,000$ \\
\hline Startup Testing & $\$ 2,784,000$ \\
\hline Total Costs - FIRST COMMERCIAL PLANT & $\mathbf{\$ 1 2 8 , 9 3 6 , 0 0 0}(1,878$ \$/kWe $)$ \\
\hline @12\% IRR - 70\% Debt @10\% & 25.04 \$/Mwh \\
\hline \multicolumn{2}{|l|}{ Operating and Maintenance Costs } \\
\hline Fuel Costs - Biomass fuel at $.83 \$ / \mathrm{mmbtu}$ & $6.94 \$ / M w h$ \\
\hline Labor O\& M Costs -27 plant employees & $2.37 \$ / M w h$ \\
\hline Fixed Non-Labor O\&M Costs & $7.72 \$ / M w h$ \\
\hline Variable Non-Labor O\&M Costs & $2.44 \$ / M w h$ \\
\hline Total Cost of Power & $\overline{44.30 ~ \$ / M w h}$ \\
\hline Follow On Plants $\left(2^{\text {nd }}\right.$ Plant and forward $)-1,572 \$ / k w e$ & $42.84 \$ / M w h$ \\
\hline \multicolumn{2}{|c|}{$\begin{array}{l}\text { FOR COMPARISON: A General Electric MS 6001B Combined Cycle Plant on natural gas. Net } \\
\text { Plant Capacity is } 74,400 \mathrm{kWe} \text { at a net plant efficiency of } 49.0 \%\end{array}$} \\
\hline Total Capital Cost - \$871 \$/kwe 12\% IRR & $17.60 \$ / \mathrm{Mwh}$ \\
\hline O\&M Costs & $7.00 \$ / \mathrm{Mwh}$ \\
\hline Fuel Costs - $\$ 2.83$ per mmbtu & $19.70 \$ / \mathrm{Mwh}$ \\
\hline Total cost of power for natural gas combined cycle plant & $\overline{44.30 \$ / M w h}$ \\
\hline
\end{tabular}

\subsubsection{Cost of Fuel / Cost of Electricity}


To determine the cost of electricity, Emery not only had to identify the capital and O\&M costs of our plant, but also determine the likely costs of fuel (in this case RDF). In order to do so, Emery used two sources so that our resulting numbers would be realistic. First, Emery used data presented by Ms. Laurie Tomczyck, P.E. from her article entitled "Engineered Fuel: Renewable Energy of The Future?" published in the journal Solid Waste Technologies in 1997. In this article, she not only cites the conversion efficiencies of MSW to dRDF, but also arrives at cost ranges in 1997 dollars. DRDF (cited as Process Engineered Fuel (PEF)) delivered cost range from $\$ 8-\$ 17 /$ ton for pellets that have a heating value of $7000 \mathrm{Btu} / \mathrm{lb}$. If the number used by Emery of $\sim 6000 \mathrm{Btu} / \mathrm{lb}$ replaces this, then delivered fuel costs would be in the range of $\$ 6.80$ $\$ 14.45 /$ ton with an average of $\$ 10.60$ per ton delivered.

Emery also conducted a separate analysis using data supplied by SPSA in order to compare the numbers cited above with real-world numbers from a plant currently operating in $2001-2002$. While densified RDF is not a fuel that is currently readily available, RDF fluff is a fuel that is currently produced at 12 locations in the U.S. The efficiency gains afforded by the EBGPS will allow for increased fuel processing and densification that is currently not practiced in the combustion-based, waste-to-energy industry (mass burn). Emery worked with the Southeastern Public Service Authority (SPSA) to evaluate the characteristics of RDF fuel as well as the population required to supply the necessary volumes of municipal solid waste to a fuel preparation plant. The SPSA facility receives approximately 660,000 tons of MSW per year wherein approximately 460,000 tons are converted into RDF "fluff" for use in a combustion boiler to run a steam turbine/generator. Densification of the fuel is an additional step necessary to provide consistent feed to the gasifier and has been included as part of the capital and operations of the Emery system. The capital and O\&M costs of the SPSA facility were used in a simple plant pro-forma in order to assume a 20 -year pay down on the capital of the new plant necessary to convert MSW-to-RDF. Domestic MSW tipping fees were averaged throughout the nation and used to determine the minimum needed for break-even operations of a fuel preparation plant. The payback of capital costs of a new fuel preparation plant would cost $\$ 15 /$ ton. The O\&M of the facility would cost $\$ 13 /$ ton. Hence break-even operations of the plant would cost $\$ 28 /$ ton. With national average tipping fees at $\$ 34 /$ ton (with many areas higher including Florida and New Jersey at $\$ 45$ and $\$ 65 /$ ton respectively), it was determined that sufficient margin was available for the plant to earn a profit without charging for the fuel. However, Emery made the added assumption that the fuel would likely be sold near $\$ 10.00 /$ ton in order to make a larger profit for the fuel preparation plant to ensure long-term economic sustainability of such a plant. 


\begin{tabular}{||c|c|c|c|}
\hline $\begin{array}{c}\text { RDF or } \\
\text { Biomass } \\
\text { Cost }\end{array}$ & $\begin{array}{c}\text { Cost of } \\
\text { Fuel }\end{array}$ & Fuel Cost & $\begin{array}{c}\text { Total Cost of } \\
\text { Power }\end{array}$ \\
\hline \$/short ton & $\begin{array}{c}\text { \$/MMBTU } \\
\text { 's }\end{array}$ & $\mathbf{\$ / M W h}$ & $\mathbf{\$ / M W h}$ \\
\hline 0 & .00 & 0.00 & 37.01 \\
\hline 3 & .25 & 2.09 & 39.10 \\
\hline 6 & .50 & 4.18 & 41.19 \\
\hline 9 & .75 & 6.27 & 43.95 \\
\hline $\mathbf{1 0}$ & $\mathbf{. 8 3}$ & $\mathbf{6 . 9 4}$ & $\mathbf{4 3 . 9 5}$ \\
\hline 12 & 1.00 & 8.36 & 47.46 \\
\hline 15 & 1.25 & 10.45 & 49.55 \\
\hline 18 & 1.50 & 12.54 & 51.64 \\
\hline 21 & 1.75 & 14.63 & 53.64 \\
\hline 24 & 2.00 & 16.73 & 55.83 \\
\hline 27 & 2.25 & 18.82 & 57.92 \\
\hline 30 & 2.50 & 20.91 & 60.10 \\
\hline \multicolumn{2}{|c|}{$\begin{array}{l}\text { Table 5. Cost of Electricity as a function of fuel cost for a } \\
71 \text { MWe equivalent plant of an Emery Biomass IGCC Plant } \\
\text { configuration necessary to achieve a 12\% IRR at 10\% Debt rate } \\
\text { over 20 years. 40.8\% Net Plant Efficiency (8365 btu/kwh) }\end{array}$} \\
\hline
\end{tabular}

Table 5. Cost of Electricity as a Function of the Cost of Fuel in 2002 Dollars

We also made the assumption that the RDF fuel could not be sold for much more than $\$ 15 /$ ton because it begins to compete with coal (unless incentive prices are offered on the sale of electricity - many stated have programs where renewable energy is given tax credits or other financial incentives for its production). Hence, Emery's analysis of fuel costs at $\$ 10.00 /$ ton was determined to be very realistic. The resulting cost of electricity was then determined based on fuel costs. Table 5 above illustrates the cost of electricity as a function of fuel cost.

In additional to the economic model created for the base-case of $71 \mathrm{MWe}$, Emery evaluated a $35 \mathrm{MWe}$ case to see how much the price of electricity would change as a function of plant size. The cost of electricity in the 35MW case only increased by 2 mils from 4.4 cents/Kwh to 4.6 cents/Kwh. However, when the plant went down to $16 \mathrm{MWe}$ in size, the lower power output coupled with similar labor costs, pushed up the price of power to over 6 cents/Kwh.

\section{Technology Development Roadmap}

This project scope was meant to ascertain the general feasibility, overall plant efficiencies, fuel flexibility, and plant economics and to develop a technology development roadmap necessary to support technology commercialization. This study was not large enough in scope to conclusively determine the detailed technical issues associated with each plant component and/or process. However, work conducted under this contract allowed Emery to clearly identify the areas of that require development and further understanding necessary to address areas of uncertainty. This detailed technology development plan is a key beneficial product of this work because it lays out a roadmap necessary for sequential development of the gasifier technology leading to commercialization at the scale proposed.

\subsection{Technology Development Phases}


The technology development roadmap includes the following 4-Phase approach with development milestones and criteria for measuring technical progress necessary to validate successes.

\section{Phase I — Integrated Gasifier Model Development Tasks:}

(1) Develop an integrated computer model that accounts for all significant interdependent chemical reactions and physical processes in order to validate the gasifier performance.

(2) Develop a computer model to predict particle heating and reaction behavior for various fuels.

(3) Optimize design of oxygen and fuel injectors.

(4) Model design options and system components to verify equipment performance and operability.

(5) Characterize byproduct and ash residue.

(6) Consider range of appropriate fuel types (agricultural residues, wood waste, animal wastes, dRDF, coal), fuel-flexibility, and feed preparation requirements.

Phase II - Component Testing - Component tests at nominally 5 pounds or less per hour to obtain certain data not available in the literature. These tests will be focused on developing chemical reaction and product characterization data to validate the models and support the integrated mock-up test.

a. Tasks (conducted in parallel with phase I):

(1) Gasifier sub-component test to validate oxygen injection design and validate gas phase and dilute particle phase reactions.

(2) Byproducts and ash characterization tests.

Phase III - Integrated Mock-up Demonstration - The integrated mock-up demonstration will be conducted at nominally $100-150$ pounds per hour. The larger scale is required to achieve appropriate integration of the heat transfer, fluid flow, and kinetic processes necessary to provide scalable data for design of the pilot plant. Integrated mock-up tests will include:

a. Tasks:

(1) Tar Reaction/Burnout

(2) Particle Reaction/burnout

(3) Wall Reactions Tests

(4) Characteristics of sorbent and capabilities in syngas cleaning.

Phase IV - Construct/Operate Commercial Prototype Plant - This plant will gasify 30 100 tons/day of feedstock. The start-up and testing during the first few months of operation will resolve any remaining technical uncertainties and validate overall gasifier performance. The commercial prototype plant will:

a. Tasks:

(1) Verify mechanical integration of gasifier subsections 
(2) Verify gasifier efficiency

(3) Verify projected range of control over $\mathrm{H}_{2}: \mathrm{CO}$

(4) Provide a performance map for feed type, throughput, steam \& oxygen ratios, etc.

(5) Validate environmental performance

(6) Verify capability/efficiency of novel sorbents

(7) Verify adsorption of pollutants on sorbents

(8) Determine disposal characteristics of spent sorbent

(9) Facilitate commercialization by: Validating performance projections; validating capital and O\&M cost projections; updating design and process models.

\section{Market Analysis}

Initial market analysis for commercial application of the EBGPS proved to be very opportunistic. Emery evaluated the market primarily from a feedstock assessment/availability viewpoint, not a demand side analysis of power sales opportunities. However, the demand side of power sales was assumed to be very strong due to recent senate mandates requiring increased use of renewable energy in order to meet renewable energy portfolio standards and the very competitive price of electricity that he EBGPS would offer the market.

When conducting market analysis for deployment opportunities, Emery kept in mind the original solicitation goal of achieving widespread regional or national deployment of the technology. Because of this, we primarily conducted analysis of MSW derived fuels to match our base-case study of power systems using RDF as primary fuel. Additionally, Dr. Tom Reed of the Biomass Energy Foundation compiled data from Oak Ridge National Lab summarizing the general domestic availability of agricultural derived biomass feedstocks at various price points.

Based on earlier analysis of converting MSW to RDF, it was determined that roughly 1 Million tons/year of raw MSW is required to provide 400,000 tons/year of dRDF (the amount needed for a $71 \mathrm{MWe}$ EBGPS at $90 \%$ annual power plant availability). Data from the North American Waste Association indicated that approximately 250 Million tons/year of MSW is generated in the U.S. Currently only $15 \%$ of this is used in waste-to-energy facilities. $85 \%$ of domestic waste goes to landfills. Emery then made two modest assessments of the waste market to arrive at potential commercial applications of the technology for RDF feeds. The first was displacement of existing combustion/incineration technology at WTE facilities. For illustration purposes, if all WTE facilities currently operating, using approximately 30 Million tons/year of MSW and generating approximately $2500 \mathrm{MWe}$, were to convert to EBGPS technology, then a total of $\sim 4000$ MWe would result based on the efficiency improvement from their current $25 \%$ overall efficiency to $40 \%$ efficiency.

Emery also evaluated the California municipal waste market, which produces 36 Million tons/year of MSW. The top 9 landfills in the state receive $44 \%$ of the annual flow of MSW (17 Million tons/year). If the EBGPS were used to convert the waste supplied to these 9 landfills to power, an equivalent of seventeen (17) 71MWe EBGPS could be installed totaling 1207 MWe of 
renewable energy in California alone. Hence numerous opportunities for 71MWe size systems exist throughout the U.S. with concentrations in the more populous regions. Agricultural based biomass fuels could be used exclusively or as a way to augment deficiencies of MSW in lower density population centers or rural areas. The primary initial barrier to such large biomass gasification power plants is the lack of fuel preparation facilities. Such facilities would need to be co-capitalized in order to provide adequate fuel supply to an EBGPS. However, early market penetration of the technology could be accomplished by using more readily available biomass fuels such as waste woods or certain agricultural crops that are available in smaller quantities (i.e. 50 - 300 tons/day) and where a higher price of electricity could be obtained. These plants would be much lower in cost (i.e. air-blown) and represent near-term opportunities that would allow the technology to be deployed in commercial markets in the very near-term.

\section{National Benefits}

Numerous national benefits can be derived the successful development and deployment of Emery's Biomass Gasification technology. Benefits include:

- Improved national security by decreased dependence on fossil fuels and most importantly, foreign fossil fuels

- No net increase of carbon dioxide emissions when using Biomass feedstocks and the potential for developing carbon sinks when $\mathrm{CO} 2$ sequestration process are included in future IGCC schemes

- Unlike Wind and Solar technology, gasification power plants will provide more jobs per installed unit of energy. This results in:

○ Long-term rural employment opportunities

- Improved rural farming economics

- Additional jobs created for waste handling and fuel preparation

- Mitigation of municipal and agricultural waste products

- Potential to significantly increase the life of landfills by decreasing the rate at which they are filled by MSW

- Ability to displace landfill methane gas emissions by mitigating the volume of waste sent to landfills

- Distributed generation benefiting local and rural economies and mitigating the need for new large scale transmission projects

- Ability to significantly increase fuel-to-electrical efficiencies using combined cycle and fuel cell power applications

- Use of gasification in many industrial manufacturing processes for power and steam needs while converting regional and/or site generated biomass feedstocks

- Ability to co-produce additional products including ultra-clean fuels and chemicals (via catalytic conversion of the syngas to liquid fuels and chemicals) for the transportation and chemical manufacturing sectors

- Ability to produce Hydrogen for the hydrogen economy if it successfully emerges

- Ability for Nation to optimize and/or diversify its energy source mix due to the fuel flexible nature of the Emery process 
- Gasifying agricultural waste, such as wheat straw, rather than burning it in the open field or using energy-intensive tillage methods for removing it from the soil surface

Regarding this last item, open field burning of agricultural residue injects pollutants into the atmosphere. Gaseous pollutants include $\mathrm{CO}$, unburned hydrocarbons (HC), NOx, and SOx. Estimates of pollutant emissions from open field burning of field crops in California re $63.8 \mathrm{~kg}$ $\mathrm{CO}$ per ton of crop residue, $4.85 \mathrm{~kg}$ of $\mathrm{HC}$ per ton, $2.9 \mathrm{~kg}$ of NOx per ton, and $1.65 \mathrm{~kg}$ of SOx per ton (Jenkins, et al., 1992). In addition, open field burning injects polycyclic aromatic hydrocarbons (PAHs) into the atmosphere. Researchers in California (Jenkins, et al., 1996) found that wheat and barley straw produced over 2,000 $\mathrm{mg}$ of PAHs per kilogram of smoke particulates. Thus, considerable environmental benefit can be gained from the proposed biomass gasification technology, just in the agricultural area alone.

Use of the syngas for downstream conversion to liquid fuels and chemicals will help to lessen U.S. energy dependence away from current crude oil supplies. Using gasification to 'economically' convert our biomass (and coal and municipal waste) resources to petroleum and chemical products will provide our country and our industries with an economical, domestic energy source for production of electrical power, liquid fuels, and chemical products that mitigate large indirect costs related to national security and protection of foreign oil assets for U.S. consumption

\section{Implementation Plan}

Emery has outlined both the technical and financial requirements necessary to commercialize the Emery Gasification process. These financial details are not included in this report, but rather are held in our internal Business Plan and available for interested parties.

New capital investments into the company will allow for the commercial deployment of the technology. New investment monies would also allow for the leveraging of additional federal and state and international funding sources to be secured to finance renewable energy projects.

In addition to securing new capital monies, Emery is currently active in discussions with various strategic and technical partners that can add value to Emery's efforts by providing direct industry experience in gasification and partners who can act as distribution channels for the use and deployment of the technology. The INEEL is viewed as a key technical partner in the near-term during early technology development phases as well as involvement in long-term development improvements and system optimizations.

\section{Conclusion}

Overall, the technical, environmental and economic performance resulting from this work, proved to be very positive relative to solicitation objectives. Nearly all of the solicitation program goals were met or exceeded. Emery's technology specifically addresses many of the critical technical and economic issues that will allow gasification to become cost competitive against other energy alternatives in both the power sector as well as the liquid fuels and 
chemicals sectors. The positive results generated, provide a strong case for continued development and commercialization of the Emery technology.

Questions, comments and/or interested parties should contact:

Benjamin D. Phillips, President

Emery Energy Company, LLC (formerly Emery Recycling Corporation)

444 East 200 South

Salt Lake City, Utah 84111 USA

Phone: 801-364-8283

Fax: 801-364-8293

Email: bphillips@emerygas.com 


\section{EMERY BIOMASS GASIFIER}

71 MWe COMBINED CYCLE

PROCESS FLOW DIAGRAM








